\title{
DETERMINATION OF THE MOST EFFECTIVE CHARACTERISTICS IN GRAIN YIELD OF BREAD WHEAT UNDER SALINITY STRESS
}

\author{
Kh. E. Ragab ${ }^{(1)^{\star}}$ and A.M. S. Kheir ${ }^{(2)}$ \\ (1) Wheat Research Department, Field Crops Research Institute, Agriculture Research \\ Centre, Egypt. \\ (2) Soil, Water and Environment Research Institute, Agriculture Research Centre, Egypt. \\ ${ }^{*}$ Corresponding author: kragab1972@yahoo.com
}

Received: May 4, 2021

Accepted: May 31, 2021

\begin{abstract}
A pots experiment was conducted in cage-house at Wheat Research Department and the laboratory of Soil Improvement and Conservation Department, Sakha Agricultural Research Station, Agricultural Research Center, Egypt in 2015/2016 and 2016/2017 seasons. The stepwise regression analysis method used to determine the most effective characteristics related to wheat grain yield under three salinity levels. The data collected on five characteristics groups i.e., seedling, phenological, spike, physiological, yield and its contributes. The results showed that, the salinity levels less than $3.5 \mathrm{dSm}^{-1}$ did not negatively affect wheat seedling growth, while, increasing salinity levels more than $3.5 \mathrm{dSm}^{-1}$ significantly decreased all studied seedling characteristics. The salinity level of $3.5 \mathrm{dSm}^{-1}$ led to earliness percentage of $4.2,4.9,3.8$ and $2.2 \%$ in booting, heading, anthesis and maturity developmental stages, respectively. Meanwhile, increasing salinity levels up to $10.5 \mathrm{dSm}^{-1}$ caused decrease for emergence speed by $21.7 \%$ and delay booting, heading and anthesis developmental stages by 3.9, 10.8 and $8.5 \%$, respectively. Salinity stress decreased flag leaf area and increased chlorophyll pigments concentration, where the increase percent was higher for chlorophyll a compared with chlorophyll $b$ and the total chlorophyll. Salinity stress decreased all studied spike characteristics with strong effect on number of kernels spike ${ }^{-1}$ and spike kernels weight. Salinity stress decreased yield and its contributes where its effect was strong on plant height, root dry weight, biological and grain yield. The stepwise regression showed that biological yield, spike kernels weight, emergence index, number of spikes pot $^{-1}$ and hundred kernels weight under salinity stress are the important selection criteria of high grain yield.
\end{abstract}

Key words: Wheat, salinity, stepwise regression, grain yield.

\section{INTRODUCTION}

Wheat is one of the oldest and most cultivated cereal species worldwide. It is globally plays an important role in food security (De Santis et al., 2018). In arid and semi-arid regions such as Egypt, salinity is one of the major factors that affect plant growth and metabolism and causing severe damage and a loss of plant productivity (Vaidyanathan et al., 2003). Improving salt tolerance of wheat genotypes considered as the most efficient way to increase wheat yield because salinity management through improved irrigation techniques or reclamation is often expensive and provides only short-term solutions for salinity problem (Amer et al., 1989). The effects of salinity stress on several growth stages of bread wheat were discussed. Seed germination is one of the most critical stages in the plant life cycle, as it directly determines the failure or success of the subsequent growth 
stages (El-Hendawy et al. 2011; Liu et al. 2018). Salinity stress may have little effect on the final germination percentage of most crops, but it might cause a significant delaying of the germination time because of a delay of water uptake as well as a decrease in the $\alpha$-amylase activities (Murtaza and Asghar 2012). Both bread and durum wheat are more sensitive to salt stress during germination than after the three-leaf stage of growth and they reported that, the tolerant genotypes can be identified at the early growth stage (Francois et al. 1986; Aflaki et al. 2017). Salinity stress caused decrease in emergence index, shoot dry weight and shoot length (Ragab and Taha 2016). Al-Ashkar (2019) evaluated wheat double haploid lines using three salinity levels; $\mathbf{0 , 1 0 0}$, and 200 $\mathrm{mM} \mathrm{NaCl}$ for 25 days and reported that shoot length and shoot dry weight were indicative of salt-tolerance, indicating their importance in improving and evaluating salt tolerant genotypes for breeding programs. The effect of $200 \mathrm{mM}$ $\mathrm{NaCl}$ salinity level on yield components and chlorophyll components in pots experiment and found that salinity stress deceased chlorophyll a, chlorophyll b and shoot dry weigh by 21,33 and $20 \%$, respectively (Tareq et al. 2011). Increasing salinity levels from 4000 to $8000 \mathrm{ppm} \mathrm{NaCl}$ decreased number of days to heading, plant height, number of spikes plot $^{-1}$, number of kernels spike ${ }^{-1}$, 1000 kernels weight and grain yield Maha et al. 2017). Salinity treatments significantly increase chlorophyll and carotenoid content per leaf area (Shah et al. 2017). Many researchers used stepwise regression analyses in order to identify the most important characteristics affecting grain yield in both normal and stress conditions. Fouad, (2018) and Abd El-Mohsen and Abd El-Shafi (2014) used stepwise regression analysis to justify the superior characteristics to use in selection for high grain yield under normal and stress conditions. The estimation of correlation and regression analysis among yield and yield components may provide effective selection criteria to improve wheat grain yield and their results observed positive phenotypic correlation for the grain yield with number of tillers plant ${ }^{-1}$ and 1000grain weight (Rasheed et al. 2015; Khames et al. 2016; Jan et al 2017). The objective of this study is to determine the most effective characteristics related to wheat grain yield under salinity stress.

\section{MATERIALS AND METHODS}

A pots experiment was conducted in cage-house at Wheat Research Department and the laboratory of Soil Improvement and Conservation Department, Sakha Agricultural Research Station, Kafrelsheikh, Agricultural Research Center, Egypt during 2015/2016 and 2016/2017 growing seasons. Eighteen bread wheat genotypes previously characterized for salinity stress (Ragab, and Kheir 2019) namely; Giza 168, Giza 171, Misr 1, Misr 2, Sakha 93, Sakha 94, Sakha 95, Gemmeiza 7, Gemmeiza 9, Gemmeiza10, Gemmeiza11, Gemmeiza12, Sids 1, Sids 12, Sids 13, Shandweel 1, Line 1 and Line 2 were used as a representative sample of bread wheat population. The experiment was conducted in $30 \times 40 \mathrm{~cm}$ black plastic bags filled with about $17 \mathrm{~kg}$ of tap water washed sand. On $25^{\text {th }}$ November (the optimum sowing date) for both 2015/2016 and 2016/2017 growing seasons, twelve uniform seeds of the studied genotypes were sown into the depth of $4 \mathrm{~cm}$. Three salt stress treatments $(3.5,7.0$, and 10.5 $\mathrm{dSm}^{-1}$ ) were induced using diluted Mediterranean seawater, in addition to the control treatment (tap water, 0.5 $\mathrm{dSm}^{-1}$ ) (Table 1). Control treatment used a concentration of $0.5 \mathrm{dSm}^{-1}$; close to the salinity of Nile river in Egypt $\left(0.7 \mathrm{dSm}^{-1}\right)$ as the main source of irrigation water. 
Table 1: Tap water / sea water mix percent, electrical conductivity (EC), cations and anions analysis of the three studied salt treatments.

\begin{tabular}{|c|c|c|c|c|c|c|c|c|c|c|c|c|}
\hline \multirow{2}{*}{$\begin{array}{c}\text { Salt } \\
\text { treatments }\end{array}$} & \multirow{2}{*}{$\begin{array}{c}\text { Tap } \\
\text { water } \\
\text { ml }\end{array}$} & \multirow{2}{*}{$\begin{array}{c}\text { Sea } \\
\text { water } \\
\text { ml }\end{array}$} & \multirow{2}{*}{$\begin{array}{c}\text { Sea } \\
\text { water } \\
\text { mix } \\
\text { percent }\end{array}$} & \multirow{2}{*}{$\begin{array}{c}E C \\
\left(\mathrm{dsm}^{-1}\right)\end{array}$} & \multicolumn{4}{|c|}{ Cation $\left(\mathrm{mgL}^{-1}\right)$} & \multicolumn{4}{|c|}{ Anions $\left(\mathrm{mgL}^{-1}\right)$} \\
\hline & & & & & $\mathrm{K}+$ & $\mathrm{Na}+$ & Mg++ & $\mathrm{Ca}++$ & so4- & CL- & HCO3- & CO3- \\
\hline control & 1000 & 0 & 0 & 0.5 & 0.22 & 1.72 & 1.38 & 1.48 & 0.32 & 0.94 & 3.54 & - \\
\hline 1 & 948 & 52 & 5.2 & 3.5 & 0.78 & 21.3 & 9.88 & 3.11 & 0.4 & 31.1 & 3.5 & - \\
\hline 3 & 881 & 119 & 11.9 & 7 & 1.52 & 42.5 & 19.75 & 6.21 & 0.92 & 65.6 & 3.47 & - \\
\hline 3 & 823 & 177 & 17.7 & 10.5 & 2.28 & 63.8 & 29.63 & 9.32 & 0.98 & 101 & 3.42 & - \\
\hline Sea water & & & & 50.7 & 11.2 & 308 & 142.9 & 45 & 2.22 & 502 & 3 & - \\
\hline
\end{tabular}

The pots irrigated every week with amounts of 2 liters $\operatorname{pot}^{-1}$ of irrigation solution corresponding to each salinity level, taking into consideration the leaching requirements to avoid salt accumulation (Letey et al. 2011). The salt stress was applied from the sowing irrigation. The NPK multi-nutrients fertilizer 20:10:20 were used by $0.5 \mathrm{~g} \mathrm{pot}^{-1}$ week $^{-1}$ dissolved in irrigation solution. Chelating microelements FULV-E (0.6\%Zn.0.2\% Cu,5,0\%Mg, 2.0\%B, $5 \% \mathrm{~N}, 4.0 \% \mathrm{~K}_{2} \mathrm{O}, 4 \% \mathrm{Fe}, 1.2 \mathrm{Mn}, 8 \%$ fulvic acid and $6 \%$ citric acid) was sprayed every week with the rate of $3 \mathrm{~cm} \mathrm{~L}^{-1}$. The plants were protected against fungi diseases using the fungicide CABRIO ${ }^{\mathrm{TM}}$ TOP $60 \% \mathrm{wg}$ with the rate of $1 \mathrm{~g} / \mathrm{L}$ and against insect damage using the insecticide NASR LATHION / CHEMINOVA $57 \%$ with the rate of $5 \mathrm{~cm} \mathrm{~L}^{-1}$. The eighteen bread wheat genotypes were arranged in randomize complete block design with three replications. After four days from sowing, the emerged seedlings were counted daily and the speed of seedling emergence was estimated by the formula described by the association of official seed analysis (AOSA, 1983) with some modifications. Emergence index $(E I)=($ No. of emerged seed / days of first count $+\ldots . .+$ (No. of emerged seed / days of final count). The grate value of El is the high speed of emergence. After twenty days from sowing, the plants were thinned and only five seedlings were carefully left in each pot to grow until maturity. From the thinned seedlings, five seedlings were used to measure shoot length (ShL, $\mathrm{cm}$ ), shoot fresh weigh (ShFW, g) and Shoot dry weigh (ShDW, g). The studied characteristics at adult plant stage were number of days to booting (DB), number of days to heading (DH), number of days to anthesis (DA), number of days to maturity (DM), plant height $(\mathrm{PH}, \mathrm{cm})$, number of tillers $\operatorname{pot}^{-1}\left(\mathrm{TP}^{-1}\right)$, number of spikes $\operatorname{pot}^{-1}\left(\mathrm{SP}^{-1}\right)$, spike length $(\mathrm{SL}, \mathrm{cm})$, number of spikelets spike ${ }^{-1}\left(S^{-1}\right)$, spike kernels weight (SKW), number of kernels spike $^{-1}\left(\mathrm{KS}^{-1}\right)$, hundred kernels weight (100KW), biological yield pot ${ }^{-1}(B Y, g)$ and grain yield $\operatorname{pot}^{-1}(G Y, g)$. After heading, flag leaf area was determined following the formula of Carleton and Foote (1965) based on mean of three main stem flag leaves. Leaf area $\left(\mathrm{cm}^{2}\right)=$ leaf length $x$ maximum leaf width $\times 0.75 \quad(0.75=$ Correction factor for family Graminae). In the first season only, after heading, three dicks ( $0.6 \mathrm{~mm}$ diameter) of the flag leaf, were taken and add to $5 \mathrm{ml}$ of extraction solution ( $\mathrm{N}, \mathrm{N}$-dimethyl formamide) and kept in dark box at $4^{\circ} \mathrm{C}$ (in the refrigerator) overnight. The absorption 
values at the specific wavelength were estimated using MILTON ROYspectronic 1201. Porra et al. (1989) equations were used to estimate the concentration in nano moles per milliliter of chlorophyll a ( $\mathrm{Chl}$ a), chlorophyll b (Chl b), and total chlorophyll total (Chl).

$\begin{aligned} & \text { Chl a } \text { concentration }=(13.71 \times \text { A663.6) }- \\ &(2.85 \times A ~ 646.6)\end{aligned}$

Chl b concentration $=(22.39 \times \mathrm{A} 646.6)$ (5.42 × A 663.6)

Total $\mathrm{Chl}$ concentration $=(8.29 \times \mathrm{A663.6})+$ (19.54 × A 646.6)

Where $A_{x x x . x}$ refers to the absorbance value at the specific wavelength (xxx.x in $\mathrm{nm})$.

After harvesting, the root system was extracted from each pot using fine tap water on $2.5 \mathrm{~mm}$ plastic mesh and dried at $65^{\circ} \mathrm{C}$ to estimate root dry weight (RDW, g). The collected data were statistically analyzed by GenStat $14^{\text {th }}$ edition microcomputer program (VSN International, 2011); multi environments trials in two factor factorial in RCBD. The means of salt treatments were obtained and mean differences were compared with least significant differences (LSD). Stepwise regression was used to automatically identify the characteristics influencing grain yield under normal and salinity stress. Multi regression analysis stepwise method among grain yield as dependent variable and the remaining studied characteristics as independent variables done using IMB ${ }^{\circledR}$ SPSS statistics version 25 (2017).

\section{RESULTS AND DISCUSSION}

The analysis of variance for seedling characteristics (Table 2) showed highly significant differences between years, genotypes, salt concentrations and their interactions for all studied characteristics. The variance of years and salinity had the main portion of total variation compared to the other source of variations. The coefficient of variation ranged from $6.1 \%$ for shoot length to $14.0 \%$ for shoot fresh weight. Regarding phenological characteristics, highly significant differences were recorded for all sources of variation and the main portion of total variation were due to years, salinity concentration and years $x$ salt concentration interaction variances. Similar results were obtained by Ragab and Taha (2016) and Maha et al. (2017) whoreported that the variance due to salinity had the major portion from the total variance. The coefficient of variation ranged from $1.3 \%$ to $6.0 \%$ for days to maturity and emergence index, respectively. For physiological characteristics, highly significant differences were found for all source of variations and the main portion of total variation was due to salinity concentration variance. The coefficient of variation ranged from $6.4 \%$ for flag leaf area to $13.0 \%$ for chlorophyll b. For spike characteristics, highly significant differences were found for all source of variations and the main portion of total variations were due to years and salinity concentration variance. The coefficient of variation ranged from $6.5 \%$ for spiklets spike $^{-1}$ to $19.0 \%$ for spike kernel weight. For yield and its contributes, highly significant differences were recorded for all sources of variation except for years in grain yield and hundred kernels weight and salt concentration genotypes interaction for hundred kernels weight . The main portion of total variation was due to salinity concentration variance in most cases. The coefficient of variation ranged from $3.9 \%$ for plant height to $22.0 \%$ for grain yield. 
Table 2: Mean squares of years (Y), genotypes (G), salt concentrations (S) and their interactions and coefficient of variation (CV \%) for seedling, phenological, physiological, spike characteristics, yield, and its contributes of the studied bread wheat genotypes.

\begin{tabular}{|c|c|c|c|c|c|c|c|c|c|c|c|}
\hline \multirow{4}{*}{ Characteristic } & \multicolumn{10}{|c|}{ Source of variance } & \multirow{4}{*}{ CV\% } \\
\hline & $\mathbf{Y}$ & Residual & S & G & $\mathrm{Y} \times \mathrm{S}$ & $Y \times G$ & $S \times G$ & $\mathbf{Y} \times \mathbf{S} \times \mathbf{G}$ & Residual & Total & \\
\hline & \multicolumn{10}{|c|}{ df } & \\
\hline & 1 & 4 & 3 & 17 & 3 & 17 & 51 & 51 & 284 & 431 & \\
\hline \multicolumn{12}{|c|}{ Seedling characteristics } \\
\hline Shoot length & $519.5^{\star \star}$ & 519.500 & $237.9^{\star \star}$ & $65.95^{\star \star}$ & $36.9^{\star \star}$ & $11.3^{\star \star}$ & $4.96^{\star \star}$ & $6.5^{\star \star}$ & 1.980 & & 6.1 \\
\hline $\begin{array}{c}\begin{array}{c}\text { Shoot fresh } \\
\text { weigh }\end{array} \\
\end{array}$ & $17.13^{\star \star}$ & 0.046 & $12.1^{\star *}$ & $1.31^{\star *}$ & $0.995^{\star \star}$ & $0.21^{\star \star}$ & $0.12^{\star \star}$ & $0.09^{\star \star}$ & 0.051 & & 15.0 \\
\hline $\begin{array}{c}\text { Shoot dry } \\
\text { weigh }\end{array}$ & $0.183^{\star \star}$ & 0.0004 & $0.113^{\star *}$ & $0.021^{\star \star}$ & $0.027^{\star \star}$ & $0.003^{\star \star}$ & $0.001^{\star *}$ & $0.001^{\star \star}$ & 0.001 & & 14.0 \\
\hline \multicolumn{12}{|c|}{ Phenological characteristics } \\
\hline $\begin{array}{c}\text { Emergence } \\
\text { index }\end{array}$ & $4994^{\star \star}$ & 0.302 & $323.4^{\star *}$ & $8.03^{\star \star}$ & $135.6^{\star \star}$ & $4.8^{\star \star}$ & $3.0^{\star \star}$ & $2.8^{\star \star}$ & 0.743 & & 6.0 \\
\hline $\begin{array}{l}\text { Days to } \\
\text { booting }\end{array}$ & $18362^{\star \star}$ & 7.321 & $3577.2^{\star \star}$ & $692.4^{\star \star}$ & $3560.1^{\star *}$ & $101.2^{\star \star}$ & $35.2^{\star \star}$ & $21.0^{\star \star}$ & 3.665 & & 2.5 \\
\hline $\begin{array}{l}\text { Days to } \\
\text { heading } \\
\end{array}$ & $21710^{\star \star}$ & 16.930 & $3434.9^{\star \star}$ & $510.1^{\star \star}$ & $2758.7^{\star \star}$ & $78.4^{\star \star}$ & $38.0^{\star \star}$ & $25.0^{\star \star}$ & 2.942 & & 2.0 \\
\hline $\begin{array}{l}\text { Days to } \\
\text { anthesis }\end{array}$ & $38344^{\star \star}$ & 19.218 & $2616.6^{\star \star}$ & $382.81^{\star *}$ & $2749.2^{\star \star}$ & $52.7^{\star \star}$ & $21.1^{\star \star}$ & $16.0^{\star \star}$ & 3.105 & & 1.8 \\
\hline $\begin{array}{l}\text { Days to } \\
\text { maturity }\end{array}$ & $30763^{\star \star}$ & 17.709 & $304.9^{\star *}$ & $200.39^{\star \star}$ & $758.0^{\star \star}$ & $35.3^{\star \star}$ & $14.4^{\star \star}$ & $11.1^{\star \star}$ & 3.418 & & 3.9 \\
\hline \multicolumn{12}{|c|}{ Physiological characteristics } \\
\hline Flag leaf area & - & - & $22251.9^{* *}$ & $1020.4^{\star \star}$ & - & - & $191.7^{\star \star}$ & - & 10.280 & & 6.4 \\
\hline Chlorophyll a & - & - & $1440.1^{\star \star}$ & $38.7^{\star \star}$ & - & - & $11.8^{\star \star}$ & - & 1.175 & & 7.2 \\
\hline Chlorophyll b & - & - & $29.8^{\star \star}$ & $4.3^{\star \star}$ & - & - & $2.4^{\star \star}$ & - & 0.314 & & 13.0 \\
\hline $\begin{array}{c}\text { Total } \\
\text { chlorophyll } \\
\end{array}$ & - & - & $1850.5^{\star \star}$ & $60.5^{\star \star}$ & - & - & $17.6^{\star \star}$ & - & 1.932 & & 7.2 \\
\hline \multicolumn{12}{|c|}{ Spike characteristics } \\
\hline $\begin{array}{c}\text { Spike kernels } \\
\text { weight }\end{array}$ & $10.6^{\star \star}$ & 0.454 & $22.4^{\star *}$ & $4.2^{\star \star}$ & $6.3^{\star \star}$ & $0.9^{\star \star}$ & $0.5^{\star *}$ & $0.4^{\star \star}$ & 0.225 & & 19.0 \\
\hline Spike length & $36.8^{\star}$ & 2.817 & $82.1^{\star *}$ & $24.9^{\star \star}$ & $9.8^{\star *}$ & $4.1^{\star \star}$ & $1.5^{\star \star}$ & $1.2^{\star \star}$ & 0.747 & & 7.9 \\
\hline$\underset{1}{\text { Spikelet spike }}$ & $0.003 \mathrm{~ns}$ & 15.358 & $215.1^{\star \star}$ & $19.5^{\star \star}$ & $20.9^{\star \star}$ & $6.3^{\star \star}$ & $3.1^{\star \star}$ & $2.5^{\star \star}$ & 1.413 & & 6.5 \\
\hline Kernels spike $^{-1}$ & $9445.0^{\star \star}$ & 19.840 & $4136.6^{\star \star}$ & $588.6^{\star \star}$ & $439.5^{\star \star}$ & $277.8^{\star \star}$ & $245.2^{\star \star}$ & $135.1^{\star \star}$ & 24.880 & & 8.5 \\
\hline \multicolumn{12}{|c|}{ Yield and its contributing characteristics } \\
\hline Tiller pot ${ }^{-1}$ & $157.7^{\star \star}$ & 0.939 & $162.1^{\star \star}$ & $324.8^{\star \star}$ & $2515.9^{\star * *}$ & $115.9^{\star \star \star}$ & $52.0^{\star \star}$ & $40.8^{\star \star}$ & 7.083 & & 12.2 \\
\hline Spike pot $^{-1}$ & $158.3^{\star *}$ & 2.630 & $345.4^{\star \star}$ & $179.4^{\star \star}$ & $170.3^{\star \star}$ & $57.7^{\star \star}$ & $23.1^{\star \star}$ & $17.1^{\star *}$ & 6.996 & & 16.0 \\
\hline Plant height & $7664.2^{\star \star}$ & 12.953 & $26149.5^{\star \star *}$ & $1030.6^{\star \star}$ & $2676.7^{\star \star}$ & $216.1^{\star \star}$ & $110.6^{\star \star}$ & $89.1^{\star \star}$ & 8.125 & & 3.9 \\
\hline $\begin{array}{c}\text { Root dry } \\
\text { weight }\end{array}$ & - & - & $481.5^{\star \star}$ & $71.3^{\star \star}$ & - & - & $10.9^{\star \star}$ & - & 1.344 & & 19.0 \\
\hline \begin{tabular}{|c|}
$\begin{array}{c}100 \text { Kernels } \\
\text { weight }\end{array}$ \\
\end{tabular} & $8.2 \mathrm{~ns}$ & 1.371 & $13.3^{\star \star}$ & $7.7^{\star *}$ & $10.2^{\star \star}$ & $1.0^{\star \star}$ & $0.4 \mathrm{~ns}$ & $0.43^{\star \star}$ & 0.264 & & 12.0 \\
\hline $\begin{array}{c}\begin{array}{c}\text { Biological } \\
\text { yield }\end{array} \\
\end{array}$ & $4452.3^{\star \star}$ & 79.640 & $45288.2^{\star \star}$ & $4646.9^{\star \star}$ & $746.1^{\star \star}$ & $704.6^{\star \star}$ & $759.7^{\star \star}$ & $479.9^{\star \star}$ & 46.630 & & 10.8 \\
\hline Grain yield & 41.7ns & 134.180 & $10604.4^{* \star}$ & $788.7^{\star \star}$ & $188.9^{\star \star}$ & $229.4^{\star \star}$ & $104.3^{\star \star}$ & $103.2^{\star \star}$ & 36.840 & & 22.0 \\
\hline
\end{tabular}

ns, ${ }^{*}$ and ${ }^{\star *}$, insignificant, significant at 0.05 and 0.01 probability levels, respectively. 


\section{Seedling characteristics}

The effects of salt concentrations on seedling, phenological, physiological, spike characteristics and yield and its contributes are listed in Table (3). Under $3.5 \mathrm{dSm}^{-1}$ salinity level, shoot length, shoot fresh weight and shoot dry weight were increased by $7.1,3.4$, and $4.8 \%$, respectively. These results indicated that the low level of salinity $\leq 3.5 \mathrm{dSm}^{-1}$ diluted seawater did not causes significant changes in wheat seedling characteristics particularly the shoot length and dry weight. The $7.0 \mathrm{dSm}^{-1}$ salinity level caused an insignificant increase in the shoot length. Significant decrease in regarding shoot fresh and dray weight with reduction percent 20.2 and 9.5, respectively (Table 3). With increase salinity level up to $10.5 \mathrm{dSm}^{-1}$, the salinity effects were more aggressive and that reflected on reduction percent values, which reached to $8.6,37.1$ and 28.6 for shoot length, shoot fresh weight and shoot dry weight respectively. Generally, the salinity level $\leq 3.5 \mathrm{dSm}^{-1}$ diluted seawater did not negatively affect wheat seedling growth. While, increasing salinity levels more than $3.5 \mathrm{dSm}^{-1}$ lead to significant decrease for all studied seedling characteristics. Similar results were reported that salinity stress decreased shoot dry weight and shoot length (Ragab and Taha 2016; Tareq et al. 2011)) indicating their importance in improving and evaluating salt tolerant genotypes for breeding programs (AlAshkar et al. 2019). Bread and durum wheat are more sensitive to salt stress during germination than after the threeleaf stage of growth and the tolerant genotypes can be identified at the early growth stage (Francois et al. 1986; Aflaki et al. 2017). Significant delaying of the germination time and decrease shot weight maybe happened by a delay of water uptake as well as a decrease in the $\alpha$-amylase activities (Murtaza and Asghar 2012).

\section{Phenological characteristics}

The emergence index was increased by $0.4 \%$ under $3.5 \mathrm{dSm}^{-1}$ salinity level. On other hand, comparing to control treatment it was significantly decreased by 14.7 and $21.7 \%$ reduction under 7.0 $\mathrm{dSm}^{-1}$ and $10.5 \mathrm{dSm}^{-1}$ salinity levels, respectively, (Table 3). Under control and $10.5 \mathrm{dm}^{-1}$ salinity levels, the number of days was increased by $\mathbf{1 0 . 2}$ days (from 73.2 to 83.4) for booting stage; by 9.2 days (from 83.3 to 94.5 ) for heading stage and by 8.0 days (from 94.4 to 102.4) for anthesis stage, but, the days to maturity did not change. On the other side, the 3.5 $\mathrm{dSm}^{-1}$ salinity level led to approximately 3 days decrease for the number of days to booting, heading, anthesis and maturity. Generally, the studied salinity levels had varying effects on the bread wheat emergence, booting, heading, anthesis and maturity development stages. The salinity level $3.5 \mathrm{dSm}^{-1}$ led to earliness by $4.2,4.9,3.8$ and $2.2 \%$ in the booting, heading, anthesis and maturity developmental stages, respectively, while, increasing salinity levels caused decrease emergence speed by $21.7 \%$ and lateness in all studied developmental stages that reached to $13.9,10.8$ and 8.5 for booting, heading and anthesis under salinity level $10.5 \mathrm{dSm}^{-1}$. Similar results were obtained by Al-Naggar et al. (2015) who confirmed that salt stress at 9000 ppm significantly increased (delaying) days to heading by $15.9 \%$ and days to maturity by $14.7 \%$ in wheat. On the other hand, Asfaw and Danno 2011 found that increased salinity levels delaying heading and Maturity of tef crop [Eragrostis tef (Zucc.) Trotter] accessions and varieties in Ethiopia. Allel et al (2019) evaluated North African barley accessions at reproductive stage against salinity and they found that the severe 
Determination of the most effective characteristics in grain yield of ............

salinity levels of $200 \mathrm{mM} \mathrm{NaCl}$ delayed heading and maturity date for the majority of moderately salt tolerant barley genotypes. In addition, they suggested that a longer heading and maturity periods may contribute to salt tolerance and delayed heading and maturity processes gives the opportunity of late differentiation and ripening, enabling the plant to maintain higher number of kernels spike ${ }^{-1}$ and consequently high grain yield. The salinity levels decreased emergence speed (Ragab and Taha 2016), delayed germination and has a little effect on the final germination percentage (Murtaza and Asghar 2012) which maybe explain the delaying of heading and maturity in wheat. On the contrary, Maha et al. (2017) reported decreasing number of days to heading as increasing salinity levels from 4000 to $8000 \mathrm{ppm} \mathrm{NaCl}$.

Table 3: Salinity effects on seedling, phenological, physiological, spike and yield and contributed characteristics.

\begin{tabular}{|c|c|c|c|c|c|c|c|c|}
\hline \multirow{2}{*}{ Characteristic } & \multicolumn{4}{|c|}{ Salt concentrations $\left(\mathrm{dSm}^{-1}\right)$} & \multirow{2}{*}{$\operatorname{LSD}_{0.05}$} & \multicolumn{3}{|c|}{ Change \% } \\
\hline & 0.5 & 3.5 & 7 & 10.5 & & 3.5 & 7 & 10.5 \\
\hline \multicolumn{9}{|c|}{ Seedling characteristics } \\
\hline Shoot length (cm) & 23.06 & 24.69 & 23.17 & 21.07 & 0.38 & 7.1 & 0.5 & -8.6 \\
\hline Shoot fresh weigh (g) & 1.78 & 1.84 & 1.42 & 1.12 & 0.06 & 3.4 & -20.2 & -37.1 \\
\hline Shoot dry weigh (g) & 0.21 & 0.22 & 0.19 & 0.15 & 0.01 & 4.8 & -9.5 & -28.6 \\
\hline \multicolumn{9}{|c|}{ Phenological characteristics } \\
\hline Emergence index & 15.68 & 15.75 & 13.37 & 12.27 & 0.20 & 0.4 & -14.7 & -21.7 \\
\hline Days to booting (day) & 73.20 & 70.10 & 74.20 & 83.40 & 0.50 & -4.2 & 1.4 & 13.9 \\
\hline Days to heading (day) & 85.30 & 81.10 & 85.70 & 94.50 & 0.44 & -4.9 & 0.5 & 10.8 \\
\hline Days to anthesis (day) & 94.40 & 90.80 & 94.30 & 102.40 & 0.47 & -3.8 & -0.1 & 8.5 \\
\hline Days to maturity (day) & 138.10 & 135.10 & 135.30 & 138.10 & 0.48 & -2.2 & -2.0 & 0.0 \\
\hline \multicolumn{9}{|c|}{ Physiological characteristics } \\
\hline Flag leaf area $\left(\mathrm{cm}^{2}\right)$ & 66.06 & 57.25 & 42.90 & 33.95 & 0.29 & -13.3 & -35.1 & -48.6 \\
\hline Chlorophyll a (nmol ml $\left.{ }^{-1}\right)$ & 9.58 & 16.93 & 17.01 & 16.69 & 0.29 & 76.7 & 77.6 & 74.2 \\
\hline Chlorophyll b $\left(\mathrm{nmol} \mathrm{ml}^{-1}\right)$ & 3.57 & 4.31 & 4.53 & 4.78 & 0.15 & 20.7 & 26.9 & 33.9 \\
\hline $\begin{array}{l}\text { Total chlorophyll (nmol } \\
\mathrm{ml}^{-1} \text { ) }\end{array}$ & 13.14 & 21.24 & 21.54 & 21.48 & 0.37 & 61.6 & 63.9 & 63.5 \\
\hline \multicolumn{9}{|c|}{ Spike characteristics } \\
\hline Spike length (cm) & 11.61 & 11.37 & 11.06 & 9.66 & 0.22 & -2.1 & -4.7 & -16.8 \\
\hline Spikelets spike $^{-1}$ & 19.62 & 18.95 & 17.97 & 16.37 & 0.30 & -3.4 & -8.4 & -16.6 \\
\hline Kernels spike $^{-1}$ & 64.07 & 61.67 & 58.67 & 49.91 & 1.30 & -3.7 & -8.4 & -22.1 \\
\hline Spike kernels weight (g) & 2.79 & 2.73 & 2.53 & 1.80 & 0.12 & -2.2 & -9.3 & -35.5 \\
\hline \multicolumn{9}{|c|}{ Yield and contributed characteristics } \\
\hline Tiller pot $^{-1}$ & 20.30 & 20.70 & 21.90 & 23.00 & 0.70 & 2.0 & 7.9 & 13.3 \\
\hline Spike pot $^{-1}$ & 17.30 & 17.80 & 16.30 & 13.80 & 0.70 & 2.9 & -5.8 & -20.2 \\
\hline Plant height (cm) & 88.27 & 82.98 & 68.79 & 53.59 & 0.76 & -6.0 & -22.1 & -39.3 \\
\hline Root dry weight (g) & 8.79 & 6.98 & 4.96 & 4.07 & 0.72 & -20.6 & -43.6 & -53.7 \\
\hline 100 kernels weight $(\mathrm{g})$ & 4.44 & 4.36 & 4.23 & 3.66 & 0.13 & \begin{tabular}{|l|}
-1.8 \\
\end{tabular} & -4.7 & -17.6 \\
\hline Biological yield (g) & 85.47 & 79.61 & 61.90 & 39.94 & 1.82 & -6.9 & -27.6 & -53.3 \\
\hline Grain yield $(g)$ & 37.30 & 34.03 & 26.35 & 15.00 & 1.60 & -8.8 & -29.4 & -59.8 \\
\hline
\end{tabular}




\section{Physiological characteristics}

Gradual increasing salinity levels for $3.5,7.0$ and $10.5 \mathrm{dSm}^{-1}$ led to significantly decreased flag leaf area with 13.3, 35.1, and $48.6 \%$ respectively. Meanwhile, salinity levels of $3.5,7.0$ and $10.5 \mathrm{dSm}^{-1}$ led to increase chlorophyll a by $76.7,77.6$ and $74.2 \%$, respectively; chlorophyll b by 20.7, 26.9 and $33.9 \%$, respectively; total chlorophyll by $61.6,63.9$ and $63.5 \%$, respectively. From these results, it can be concluded that, salinity stress caused decreasing flag leaf area and increasing chlorophyll pigments concentration, with high increase percent for chlorophyll a compared with chlorophyll $b$ and the total chlorophyll.

Shah et al. (2017) confirmed that wheat plants under increasing saline treatments exhibited more green leaves compared to non-saline conditions and significant increase the chlorophyll and carotenoid content per leaf area at all levels of applied fertilizer. On the contrary, Tareq et al. (2011) found that $200 \mathrm{mM}$ salinity level decreased chlorophyll a and chlorophyll b by 21 and $33 \%$ respectively. salinity has inhibitory effects on physiological aspects of wheat, which impair the growth and yield of the crop (Rani 2019).

\section{Spike characteristics}

Increasing salinity levels from control to $10.5 \mathrm{dSm}^{-1}$ caused decrease spike length from $11.61 \mathrm{~cm}$ to $9.66 \mathrm{~cm}$ with reduction percent reached $16.8 \%$; number of spikelet spike ${ }^{-1}$ from 19.62 to $16.37 \mathrm{~cm}$ with reduction percent reached $16.6 \%$; number of kernels spike ${ }^{-1}$ from 64.07 to 49.91 with reduction percent reached 22.1\%; spike kernels weight from 2.79 to $1.80 \mathrm{~g}$ with reduction percent reached $35.5 \%$ (Table 3). Generally, salinity stress led to decrease all studied spike characteristics with strong effect on number of kernels spike ${ }^{-1}$ and spike kernels weight. Maha et al. (2017) reported decreasing number of kernels spike $^{-1}$ as increasing salinity levels from 4000 to 8000 ppm NaCl.

\section{Yield and its contributing characteristics}

The number of tillers $\operatorname{pot}^{-1}$ was increased from $\mathbf{2 0 . 3}$ for control to $\mathbf{2 3 . 0}$ for $10.5 \mathrm{dSm}^{-1}$ (13.3\%). Meanwhile the number of spikes pot ${ }^{-1}$ was decreased from 17.3 for control to 13.8 for $10.5 \mathrm{dSm}^{-1}(20.2 \%)$. As salinity levels were elevated infertile tillers increased but, fertile ones were reduced. Increasing salinity levels from control to $10.5 \mathrm{dSm}-1$ caused decrease plant height from 88.27 to $53.59 \mathrm{~cm}$ with reduction percent reached $39.3 \%$; root dry weight from 8.79 to $4.07 \mathrm{~g}$ with reduction percent reached $53.7 \% ; 100$ kernels weight from 4.44 to $3.66 \mathrm{~g}$ with reduction percent reached $17.6 \%$; biological yield from 85.47 to $39.93 \mathrm{~g}$ with reduction present reached $53.3 \%$; grain yield from 37.3 to $15.0 \mathrm{~g}$ with reduction reached $59.8 \%$. These results showed that salinity stress decreased yield and its contributing characteristics with strong effect on plant height, root dry weight, biological and grain yield. Tareq et al. (2011) studied salinity ( 0 and 200 $\mathrm{mM} \mathrm{NaCl}$ ) effects on yield components and chlorophyll components in pots experiment and reported that salinity stress caused significant decrease for number of tillers plant $^{-1}$, number of spikes plant $^{-1}$ and 100 kernels weight. Ragab and Taha (2016) reported that salinity (seawater dilution) caused significant decrease of plant height, biological yield, grain yield and 100 kernels weight. Maha et al (2017) reported decreasing with increasing salinity levels (4000 and $8000 \mathrm{ppm} \mathrm{NaCl}$ ) for plant 
height, number of spike $\operatorname{pot}^{-1}$, and 1000 kernels weight.

\section{Stepwise regression analysis}

Stepwise regression analyses were done in order to catch the most important characteristics contributing to bread wheat grain yield under control and the three salt concentrations (Table 4).

The analysis under $0.5 \mathrm{dSm}^{-1}$ salt concentration (control) was over in six steps. Biological yield, spike kernels weight, spike length, plant height, shoot fresh weight and number of spikes pot $^{-1}$ were remained in the final model, respectively, $\left(R^{2}=0.72\right)$. The formula of the final model was $\widehat{Y}=14.21+0.34 \mathrm{X} 1+$ $8.91 \times 2-2.20 \times 3-0.26$ X4 + 5.93 X5 + 0.41 $X 6$. With respect to the positive and significant regression coefficient of biological yield, spike kernels weight, shoot fresh weight and number of spikes pot $^{-1}$, it could be indicated that increasing the values of this characteristics would increase the grain yield. Considering the negative and significant regression coefficient of spike length and plant height, it could be indicated that increasing the values of this traits might decrease the grain yield.

Table 4: Result of stepwise regression analysis for grain yield in bread wheat genotypes under control and three salt concentrations.

\begin{tabular}{|c|c|c|c|c|c|c|c|}
\hline \multirow[t]{2}{*}{ Model } & \multicolumn{2}{|c|}{$\begin{array}{l}\text { Unstandardized } \\
\text { Coefficients }\end{array}$} & \multirow{2}{*}{$\begin{array}{c}\begin{array}{c}\text { Standardized } \\
\text { Coefficients }\end{array} \\
\text { Beta } \\
\end{array}$} & \multirow[t]{2}{*}{$\mathbf{t}$} & \multirow{2}{*}{$\begin{array}{c}\text { P. } \\
\text { value }\end{array}$} & \multirow{2}{*}{$\begin{array}{c}\mathbf{R}^{2} \\
\text { model }\end{array}$} & \multirow{2}{*}{$\begin{array}{c}\text { Adjusted } \\
\mathbf{R}^{2} \\
\text { Model }\end{array}$} \\
\hline & $\mathbf{B}$ & Std. Error & & & & & \\
\hline \multicolumn{8}{|c|}{$0.5 \mathrm{dSm}^{-1}$ Salt concentration (control) } \\
\hline (Constant) & 14.21 & 8.37 & & 1.70 & 0.09 & \multirow{7}{*}{0.72} & \multirow{7}{*}{0.71} \\
\hline Biological Yield (x1) & 0.34 & 0.04 & 0.67 & 7.93 & 0.00 & & \\
\hline Spike kernels weight (x2) & 8.91 & 1.26 & 0.56 & 7.06 & 0.00 & & \\
\hline Spike Length(x3) & -2.20 & 0.68 & -0.24 & -3.24 & 0.00 & & \\
\hline Plant Height (x4) & -0.26 & 0.08 & -0.25 & -3.31 & 0.00 & & \\
\hline shoot fresh weight(x5) & 5.93 & 1.87 & 0.21 & 3.18 & 0.00 & & \\
\hline Spikes pot ${ }^{-1}(x 6)$ & 0.41 & 0.20 & 0.16 & 2.02 & 0.05 & & \\
\hline Model formula & \multicolumn{7}{|c|}{$\widehat{Y}=14.21+0.34 X 1+8.91 X 2-2.20 X 3-0.26 X 4+5.93 X 5+0.41 X 6$} \\
\hline \multicolumn{8}{|c|}{$3.5 \mathrm{dSm}^{-1}$ Salt concentration } \\
\hline (Constant) & -18.51 & 6.43 & & -2.88 & 0.01 & \multirow{5}{*}{0.61} & \multirow{5}{*}{0.59} \\
\hline Biological Yield (x1) & 0.19 & 0.04 & 0.41 & 5.32 & 0.00 & & \\
\hline Spike kernels weight (x2) & 4.77 & 1.20 & 0.33 & 3.98 & 0.00 & & \\
\hline Spikes pot $^{-1}(\times 3)$ & 0.52 & 0.17 & 0.24 & 3.05 & 0.00 & & \\
\hline Plant Height (x4) & 0.18 & 0.08 & 0.20 & 2.28 & 0.03 & & \\
\hline Model formula & \multicolumn{7}{|c|}{$\widehat{Y}=-18.51+0.19 X 1+4.77 X 2+0.52 X 3+0.18 X 4$} \\
\hline \multicolumn{8}{|c|}{$7 \mathrm{dSm}^{-1}$ Salt concentration } \\
\hline (Constant) & 0.04 & 1.97 & & 0.02 & 0.98 & \multirow{3}{*}{0.76} & \multirow{3}{*}{0.66} \\
\hline Biological Yield (x1) & 0.28 & 0.03 & 0.63 & 9.27 & 0.00 & & \\
\hline Spike kernels weight (x2) & 3.49 & 0.84 & 0.28 & 4.19 & 0.00 & & \\
\hline Model formula & \multicolumn{7}{|c|}{$\widehat{Y}=0.04+0.28 X 1+3.49 X 2$} \\
\hline \multicolumn{8}{|c|}{$10.5 \mathrm{dSm}^{-1}$ Salt concentration } \\
\hline (Constant) & -1.22 & 2.92 & & -0.42 & 0.68 & \multirow{6}{*}{0.79} & \multirow{6}{*}{0.74} \\
\hline Biological Yield (x1) & 0.18 & 0.03 & 0.38 & 5.54 & 0.00 & & \\
\hline Spike kernels weight (x2) & 2.22 & 0.75 & 0.24 & 2.96 & 0.00 & & \\
\hline Emergence Index(x3) & -0.39 & 0.16 & -0.13 & -2.42 & 0.02 & & \\
\hline Spikes pot ${ }^{-1}(x 4)$ & 0.35 & 0.09 & 0.24 & 3.74 & 0.00 & & \\
\hline 100kernels weight (x5) & 1.37 & 0.58 & 0.21 & 2.38 & 0.02 & & \\
\hline Model formula & \multicolumn{7}{|c|}{$\widehat{Y}=-1.22+0.18 X 1+2.22 \times 2-0.39 \times 3+0.35 \times 4+1.37 \times 5$} \\
\hline
\end{tabular}


The regression analysis under 3.5 was over in four steps. Biological yield, spike kernels weight, number of spikes pot ${ }^{-1}$ and plant height were remained in the final model, respectively, $\left(R^{2}=0.76\right)$. The formula of the final model was $\widehat{Y}=-18.51$ $+0.19 X 1+4.77 \times 2+0.52 X 3+0.18 X 4$. Positive and significant of the regression coefficient of the import characteristics indicated that increasing the values of these characteristics would increase the grain yield.

Regarding the $7.0 \mathrm{dSm}^{-1}$ salt concentration, the regression analysis was over in only two steps. Biological yield and spike kernels weight were remained in the final model, respectively, $\left(R^{2}=0.61\right)$. The formula of the final model was $\widehat{Y}=0.04+0.28 \mathrm{X} 1+3.49 \mathrm{X} 2$. Positive and significant of the regression coefficient of the two characteristics indicated that increasing the values of these characteristics would increase the grain yield.

The regression analysis under $\mathbf{1 0 . 5}$ $\mathrm{dSm}^{-1}$ was over in five steps. Biological yield, spike kernels weight, emergence index, number of spikes $\operatorname{pot}^{-1}$ and 100 kernels weight were remained in the final model, respectively, $(\mathrm{R} 2=0.79)$. The formula of the final model was $\widehat{Y}=1.22$ $+0.18 \times 1+2.22 \times 2-0.39 \times 3+0.35 \times 4+$ 1.37 X5. Positive and significant of the regression coefficient of biological yield, spike kernels weight, number of spikes pot $^{-1}$ and 100 kernels weight indicated that increasing the values of these characteristics would increase the grain yield. In general, biological yield, spike kernels weight and number of spike pot ${ }^{-1}$ characteristics were import by the stepwise regression under both control and salinity treatments, so these characteristics had an important role as selection criteria of the high grain yield under both normal and salinity stress. These results were in agreement with those found by Fouad (2018) who used stepwise multiple linear regression analysis and they revealed that number of kernels spike ${ }^{-1}$, number of spike plant ${ }^{-1}$ and 100 kernels weight were the most affected characteristics on grain yield under both normal and stress conditions (water regime). Abd El-Mohsen and Abd El-Shafi (2014) reported stepwise multiple linear regression analysis revealed that four traits, i.e., the number of tillers plant ${ }^{-}$ 1 , the number of grains spike ${ }^{-1}$ and the 1000 grain weight with $R^{2}=97.29 \%$, had justified the best grain yield prediction model under normal condition. Gholizadeh (2014) reported that the biological yield, harvest index and chlorophyll content were the most important traits influencing seed yield under saline soil. In addition, Rasheed et al (2015), Khames et al. (2016) and Jan et al. (2017) observed positive phenotypic correlation for the grain yield with tillers plant $^{-1}$ and 1000-grain weight. Hannachi et al. (2013) reported that under rainfed environment the biomass and harvest index are good measurement for predicting grain yield.

\section{CONCLUSION}

The salinity level of $3.5 \mathrm{dSm}^{-1}$ led to earliness by $4.2,4.9,3.8$ and $2.2 \%$ in the booting, heading, anthesis and maturity developmental stages, respectively. While, increasing salinity levels $>3.5$ $\mathrm{dSm}^{-1}$ caused decrease emergence speed by $21.7 \%$ and delaying in all studied developmental stages that reached to 13.9, 10.8 and 8.5 for booting, heading and anthesis under $10.5 \mathrm{dSm}^{-1}$ salinity level. Salinity stress decreased flag leaf area and increased chlorophyll pigments concentration, with high increase percent for chlorophyll a compared with chlorophyll b and the total chlorophyll. Salinity stress decreased all studied spike characteristics with strong effect on number of kernels spike ${ }^{-1}$ and spike kernels weight. Salinity stress decreased 
yield and its contributing characteristics with strong effect on plant height, root dry weight, biological and grain yield. The stepwise regression confirmed that biological yield, spike kernels weight and number of spikes $\operatorname{pot}^{-1}$ characteristics had an important role for selection criteria of high grain yield under both control and salinity stress.

\section{ACKNOWLEDGMENTS}

The authors are thankful to Wheat Research Department, Field Crops Research Institute, Agricultural Research Centre for providing the research facilities and grateful support rendered by Prof. A.M. Menshawy during data analysis.

\section{REFERENCES}

Abd El-Mohsen, A. A. and M. A. Abd ElShafi (2014). Regression and path analysis in Egyptian bread wheat. J. Agri-Food \& Appl. Sci., 2 (5): 139-148.

Aflaki F., M. Sedghi, A. Pazuki and M. Pessarakli (2017). Investigation of seed germination indices for early selection of salinity olerant genotypes. Emir J Food Agric. 29(3):222-226. DOI: 10.9755/ejfa.201612-1940

Al-Ashkar I., A. Alderfasi, S. El-Hendawy, N. Al-Suhaibani, S. El-Kafafi and M.F. Seleiman (2019). Detecting salt tolerance in doubled haploid wheat lines. Agronomy., 9, 211; doi:10.3390 / agronomy 9040211

Allel, D., A. B. Amar, M. Badri and C. Abdelly (2019). Evaluation of salinity tolerance indices in North African barley accessions at reproductive stage. Czech Journal of Genetics and Plant Breeding, 55(2): 61-69. https://doi.org/10.17221/50/2017CJGPB.

Al-Naggar, A. M. M., S. R. S. Sabry, M. M. M. Atta and Ola M. Abd El-Aleem (2015). Effects of salinity on performance, heritability, selection gain and correlations in wheat (Triticum aestivum L.) doubled haploids. Sci. Agri. 10 (2), 2015: 70-83. DOI:

10.15192/PSCP.SA.2015.10.2.7083

Amer, M.H., S. El-Guindy and W. Rafla (1989). Economic justification of drainage projects in Egypt. In: Amer, M.H., Ridder, N.A., (Eds.), Land Drainage in Egypt. Drainage Research Institute, Cairo, pp 327-339.

Asfaw, K. G. and F. I. Danno (2011). Effects of salinity on days to heading (DTH), days from heading to maturity (DHTM) and days to maturity (DTM) of tef [Eragrostis tef (Zucc.) Trotter] accessions and varieties in Ethiopia. Asian J. Agric. Sci., 3(4): 250-256.

Association of Offical Seed Analysis (A.O.S.A) (1983). Seed vigor testing handbook. Contribution No.32 to the.handbook on seed testing. Association of official seed analysis. Springfield, IL.

Carleton, M, Foote K. (1965). A comparison of methods for estimating total leaf area of barley plants. Crop Sci; 5(6): 602-603.

De Santis, M.A., O. Kosik, D. Passmore, Z. Flagella, P.R Shewry and A. Lovegrove (2018). Comparison of the dietary fibre composition of old and modern durum wheat (Triticum turgidum spp. durum) genotypes. Food Chem. 244, 304-310. https://doi.org/10.1016/j.foodchem.201 7.09.143

El-Hendawy, S.E., Y. Hu, J. I. Sakagami and U. Schmidhalter (2011). Screening Egyptian wheat genotypes for tolerance at early growth stages. International Journal of Plant Production 5 (3): 283-298.

Fouad, H.M. (2018). Correlation, Path and Regression Analysis in Some Bread Wheat (Triticum aestivum L) 
Genotypes under Normal Irrigation and Drought Conditions Egypt. J. Agron. Vol. 40, No.2, pp. 133 - 144 .

Francois, L. E., E.V. Maas, T. J. Donovan and V.L. Youngs (1986). Effect of salinity on grain yield and quality, vegetative growth and germination of semi-dwarf and durum wheat. Agron J. 78:1053-1058.

VSN International (2011). GenStat for Windows 14th Edition. VSN International, Hemel Hempstead, UK. Available online www.genstat.co.uk.

Gholizadeh, A., H. Dehghani and J. Dvorak (2014). Determination of the most effective traits on wheat yield under saline stress Agricultural Advances .3(4) 103-110 ISSN 22517820 doi: 10.14196/aa.v3i4.1304

Hannachi, A., Z. Fellahi, H. Bozerzour and A. Boutekrrabt (2013). Correlation, Path Analysis and Stepwise Regression in Durum Wheat (Triticum Durum Desf.) under Rainfed Conditions. Journal of Agriculture and Sustainability ISSN 2201-4357 Volume 3, Number 2, 2013, 122-131

IBM Corp. Released (2017). IBM SPSS Statistics for Windows, Version 25.0. Armonk, NY: IBM Corp.

Jan, N., E.P. Lal, S.C. Kashyap and G.A. Parr (2017). Character association and path analysis in wheat (Triticum aestivum $L$ em thell) under temperate conditions of Kashmir, India. Plant Archives, 17 (1), 43-50.

Khames, K. M., A. Abo-Elwafa, A.M. Mahmud and A. Hamada (2016). Correlation, path-coefficient, normal and stepwise regression analyses via two cycles of pedigree selection in bread wheat (Triticum aestivum L). Assiut J. Agric. Sci. 47(4), 84-108.

Letey, J., G. J. Hoffman, J. W. Hopmans, S. R. Grattan, D. Suarez, D. L. Corwin, J. D. Oster, L. Wu and C. Amrhein (2011). Evaluation of soil salinity leaching requirement guidelines. Agricultural Water Management 98 (4): 502-6. doi: https://doi.org/10.1016/j.agwat.2010.08 .009 .

Liu L., W. Xia, H. Li, H. Zeng, B. Wei, S. Han, C. Yin and AL. Villasuso (2018). Salinity inhibits rice seed germination by reducing $\alpha$-amylase activity via decreased bioactive gibberellin content. Front Plant Sci. 9:275- 284. doi:10.3389/fpls.2018.00275.

Maha, A. Gadallah, Sanaa, I. Milad, Y. M. Mabrook, Amira, Y. Abo Yossef and M. A. Gouda (2017). Evaluation of Some Egyptian Bread Wheat (Triticum aestivum) Cultivars under Salinity Stress. Alexandria Scince exchange Journal. Vol.38, No. 262 2. April-June

Murtaza, G. and R. Asghar (2012). $\alpha-$ amylase activities during seed development and germination in pea (Pisum sativum L.) treated with salicylic acid. Pak J Bot. 44(6):18231829.

Porra, R.J., W.A. Thompson, P. E. Kriedemann (1989). Determination of accurate extinction coefficients and simultaneous equations for assaying chlorophylls $a$ and $b$ extracted with four different solvents: verification of the concentration of chlorophyll standards by atomic absorption spectroscopy. Biochimica et Biophysica Acta, 975:384-394.

Ragab, Kh. E. and A. M. S. Kheir (2019). Characterizing some Egyptian bread wheat cultivars for salinity tolerance. J. of Plant Production, Mansoura Univ., Vol. 10 (12): 1043 - 1049.

Ragab, Kh. E. and N. I. Taha (2016). Evaluation of nine Egyptian bread wheat cultivars for salt tolerance at seedling and adult-plant stages. J. Plant production, Mansora Univ., Vol. 7 (2): 147-159 
Rani, S., M. K.Sharma, N. Kumar and Neelam (2019). Impact of salinity and zinc application on growth, physiological and yield traits in wheat. Current Scince, 116, 8, 25 APRIL

Rasheed, B., Rasheed, H.U., Khan, A. and Farid, A. (2015). Association and path analysis of exotic wheat genotypes for yield and yield components. J. Agric. Sci. Res. 2(2), 21-28.

Shah, S. H., R. Houborg and M. F. McCabe (2017). Response of Chlorophyll, Carotenoid and SPAD502 Measurement to Salinity and Nutrient Stress in Wheat (Triticum aestivum L.) Agronomy 2017, 7, 61. doi: 10.3390/agronomy7030061

Tareq, M. Z., M. A. Hossain, A. M. Mojakkir, R. Ahmedr and M. S. A. Fakir (2011). Effect of salinity on reproductive growth of wheat. Bangladesh J. Seed Sci. \& Tech. 15'(I \&2): $11 \mathrm{l}-1 \mathrm{l}$.

Vaidyanathan, H., P. Sivakumar, R. Chakrabarty and G. Thomas (2003). Scavenging of reactive oxygen species in $\mathrm{NaCl}$-stressed rice (Oryza sativa L.): differential response in highyielding and sensitive varieties. Plant Science 165, 1411-1418. 
تحديد الصفات الاكثر تأثيرا في محصول الحبوب لقمح الخبز تحت الاجهاد الملحي

خالا الامرداش رجب(1)، أحمد محمد سعد خير(2)

(1) قسم بحوث القمح -معهل بحوث المحاصيل الحقلية -مركز البحوث الز راعية -مصر

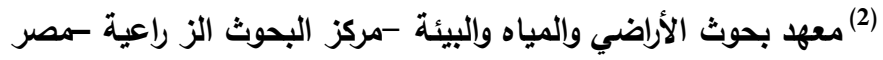

الملخص العربى

تم إجراء هذا البحث في الصوية السلكية (تجرية أصص) في قسم بحوث القمح - معهد بحوث المحاصيل الحقلية ومعمل قسم بحوث تحسين وصيانة الأراضي - معهل بحوث الأراضي والمياه بمحطة البحوث الزراعية بسخا فئه -كفر الثيخ

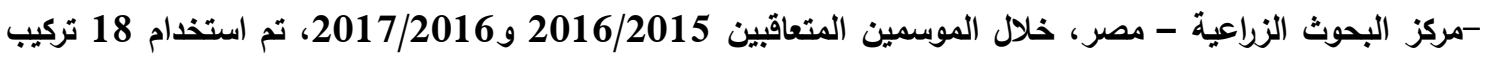
وراثي من قمح الخبز للقمح. يهاف هذا البحث إلى تحديد الصفات الأكثر تأثيرا في محصول الحبوب تحت الاجهاد الملحي. تم ترتيب جميع المعاملات قطاعات كاملة العشوائية بثلاث مكررات. وسجلت البيانات على خمس مجموعات من الصفات وهي صفات البادرة والصفات الفينولوجية والفسيولوجية وصفات السنبلة وصفات المحصول ومكوناته. تم إجراء المباء التحليل

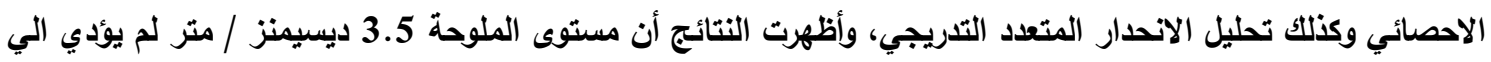
تاثير سلبى على نمو بادرة القمح كما أدى إلى التبكير بنسبة 4.2 ، 4.9 ، 3.8 و 2.2 ٪ في مراحل الحبلان والطرد والتزهير والنضج الفسيولوجي على الترتيب، بينما تسبيت زيادة مستويات الملوحة حتي 10.5 ديسيمنز / متر في تقليل سرعة الانبات بنسبة 21.7٪ وتأخر في جميع مراحل التظور التي تمت دراستها والتي بلغت 3.9 و 10.8 و 8.5 \% 8.5 و في مراحل الحبلان والطرد والتزهير على الترتيب ، كما تسبب الإجهاد الملحي في تناقص مساحة ورقة العلم وزيادة تركيز أصباغ الكلوروفيل ، مع زيادة كبيرة في الكلوروفيل (أ) مقارنة بالكلوروفيل (ب) والكلوروفيل الكلي. كما أدى إجهاد الملوحة إلى تقليل جميع صفات السنبلة المدروسة مع تأثير قوي على عدد ووزن حبوب السنبلة. قلل الإجهاد الملحي من

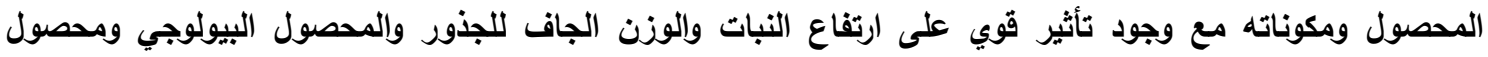

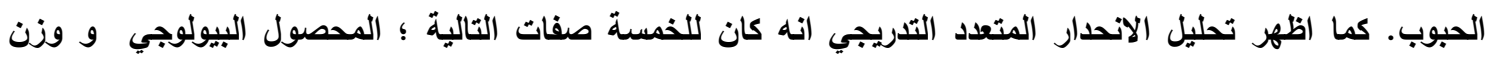
حبوب السنبلة و سرعة الانبثاق و عدد السنابل لكل اصيص و وزن الاندار 100 حبة تأثيرا كبيرا في محصول الحبوب و بالتالي يمكن استخذامها لانتخاب المحصول العالي تحت ظروف الاجهاد الملدي.

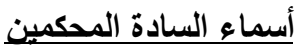

كلية الزراعة - جامعة كفر الثيخ

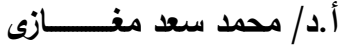

أ.د/ إبراهيم حسينى درويث كلية الزراعة - جامعة المنوفية 